Zaaiman, SJ

Noordwes-Universiteit, Potchefstroom

$\&$

Rautenbach, EJ

Ned Geref Kerk, Kakamas

\title{
'n Beoordeling van die metodologiese uitgangspunte van die Ned Geref Kerk se Kerkspieëls
}

\begin{abstract}
An evaluation of the methodological premises of the Dutch Reformed Church's "Kerkspieëls" (surveys reflecting the state of the Church)

The Dutch Reformed Church conducted eight surveys reflecting the state of the church since 1981. This article investigates the methodology of these surveys. In separate sections the problem-statement, sampling, administration of the response rate, the validity and reliability of the surveys are analysed. It is found that the surveys are not properly theoretical based, the sampling does not fulfil applicable assumptions, the response rate declined considerably in following surveys, the validity criteria are not satisfied and the standards of reliability are not adhered to. In view of this the article concludes that the Dutch Reformed Church will have to ensure a thorough ecclesiological reasoning that informs the operationalisation of the surveys and their problem-statements. The church also needs to involve experts on survey methodology in designing its surveys. For successful surveys the church will therefore have to ensure that expertise, means and support systems are properly utilised.
\end{abstract}

\section{INLEIDING}

Die Ned. Geref. Kerk het vanaf 1981 agt Kerkspieël-opnames ${ }^{1}$ onderneem ${ }^{2}$. Met verloop van tyd het die doel, benadering en uitvoering van die Kerkspieëls verander om aan te pas by veranderde omstandighede, verskillende beklemtonings van die verskillende navorsingspanne en begrotingsbeperkings. Die Kerkspieëls het dus ingespeel op die veranderde inligtingsbehoeftes van die kerk en gepoog om die afgelope 30 jaar daaraan te voldoen. Dit is gedoen met die veronderstelling dat die inligting wat die Kerkspieëls gegenereer het as geldig en betroubaar beskou kan word - dat dit ' $n$ ware spieël van die Kerk bied. Daarom is dekades lank voortgegaan om in hierdie opnames te belê.

Hierdie artikel fokus op die Kerkspieëls se navorsingsmetodologie. Die doel van die artikel is dus om vas te stel of die metodologie van so 'n aard was dat die Ned. Geref. Kerk se vertroue in die Kerkspieëls se inligting geregverdig was. Derhalwe bied hierdie artikel 'n evaluering van die uitgangspunte vir Kerkspieëls se navorsings-metodologie. Hierdeur wil die artikel 'n bydrae lewer tot die verbetering van die kwaliteit van die inligting wat deur Kerkspieëls tot die kerk se beskikking gestel word.

Wanneer navorsing deur 'n opname onderneem word, is daar ' $n$ aantal kritieke faktore

1 Die jaar waarin elke Kerkspieëlopname onderneem is, word in Tabel 1 aangedui.

2 Hierdie artikel behandel nie Kerkspieël 2010 nie. 
waaraan die navorsing moet voldoen:

1. Die teoretiese begronding van die opname moet bevredigend wees.

2. Die probleemstelling/doelstelling/vraagstelling wat die opname aanspreek moet helder geformuleer wees.

3. Die konseptualisering en operasionalisering van die opname moet geldig en betroubaar wees en moet in die meetinstrument reflekteer.

4. Die steekproef moet voldoen aan die vereistes wat gestel word vir die betrokke steekproeftegniek.

5. Die responskoers moet bevredigend wees.

6. Die ontledingstrategie moet paslik vir die probleemstelling/doelstelling/vraagstelling wees.

Weens die beperkings van 'n artikel word die Kerkspieëls hier net in die lig van punte $a, b, d$ en e beoordeel. Hierdie evaluering geskied aan die hand van die metodologiese afdelings/notas wat die Kerkspieëlverslae vergesel het en in die lig van die metodologiese beginsels wat met opnames verband hou.

Daar kan verskillende beskouings bestaan oor hoe tegnies die metodologiese verantwoording van 'n opname in die meegaande verslag behoort te wees. Die doel van die verslag kan gewoon wees om die bevindings van die opname mee te deel aan ' $n$ gehoor wat nie in die metodologie belangstel nie. In só 'n geval kan die metodologiese verduideliking dan in ander dokumente gegee word soos met die navorsingsvoorstel of ' $n$ aparte metodologiese uiteensetting. In die geval van die Kerkspieëls is egter gepoog om die basiese metodologiese uitgangspunte binne die verslae in te werk.

Die metodologiese verduideliking by die verskillende verslae was egter beperk:

- Kerkspieël 1981: In die verslag se inleiding is die volledigste metodologiese uiteensetting met 'n teoretiese begronding van al die Kerkspieëls aangebied.

- Kerkspieël 1985: In die verslag is die metodologiese verduideliking verkort sonder 'n teoretiese begronding en as ' $n$ bylae by die verslag ingesluit.

- Kerkspieël 1989 - 2004: In hierdie verslae was die metodologiese verduideliking ook kort en is dit in bykans elke opvolgende Kerkspieël woordeliks herhaal.

- Kerkspieël 2006: Net kort metodologiese verduidelikings is as 'n inligtingstuk met hierdie Kerkspieël se verslag aangebied. Daar word gemeld dat die metodologie verband hou met die "Church Live Surveys", 'n Australiese opname.

Dit is hoofsaaklik hierdie metodologiese uiteensettings in die Kerkspieëlverslae wat as basis gedien het vir die metodologiese beoordeling van die Kerkspieëls in die volgende onderafdelings.

\section{PROBLEEMSTELLING EN TEORETIESE BEGRONDING}

'n Navorsingsprojek word onderneem om 'n probleemstelling/doelstelling/vraagstelling (voortaan slegs "probleemstelling"3) aan te spreek. In die beoordeling van die Ned. Geref. Kerk se Kerkspieëls, is die geformuleerde probleemstelling in die Kerkspieëlverslae ${ }^{4}$ die vertrekpunt vir hierdie beoordeling. Hierdie probleemstelling was deurgaans betreklik vaag geformuleer

3 Tegnies kan onderskei word tussen probleemstelling, doelstellings en vraagstellings. In wese kom dit daarop neer dat die navorsing 'n sekere gestelde saak moet navors wat gemotiveer kan word. Die onderskeid tussen probleemstelling, doelstelling en vraagstelling word dus nie verder in hierdie artikel beredeneer nie. Daar word bloot na probleemstelling verwys as die saak/sake wat die Kerkspieëls ondersoek.

4 In die Kerkspieëlverslae word nêrens daarna verwys dat die probleemstelling van die opnames elders geformuleer was nie. Gevolglik word aangeneem dat die enigste formulering dié is wat in die verslae voorkom. 
soos hieronder aangedui word.

Die hoofopdrag van die Algemene Sinode vir Kerkspieël 1981 was vir'n kerklike sensusopname waardeur die kenmerke van lidmate vasgestel en getabuleer kon word (KS1981, 6). Daar is nie gerapporteer hoe tot ' $n$ besluit gekom is oor watter lidmaatkenmerke in hierdie kerklike sensus as belangrik beskou word nie. 'n Gelyklopende doelwit met die sensus was om Ned. Geref. lidmate op te spoor (KS1981, 9).

Die leidende rol van Sakkie van Eeden, as sosioloog, in Kerkspieël 1981 is opvallend. Hy het dit as 'n sosiaal-demografiese opname beskou wat vir diagnoses en afleidings swaar op sosiologiese beskouings leun (KS1981, 11). Sy uitgangspunt was dat die sosiologiese benadering die teoloog kan "begelei om verbande tussen verskynsels te sien, verklarings te formuleer en, bowenal, om bo empiriese strukture uit te styg en teoloë [te] help verstaan hoekom die kerk is soos dit is soos blyk uit empiriese data" (KS1981, 8). Volgens hom moet die sosiologiese ondersoek aandui wat die kerk "is". Dit kan dan gekontrasteer word met die protestantse teoloog se beskouing van wat die kerk "behoort" te wees (KS1981, 8). Cohen kritiseer hierdie benadering tot navorsing wat as uitgangspunt het dat: "... factual statements are typically 'is' statements and value judgments are typically 'ought' or 'should' statements; that the decision about factual statements involves truth or falsity, while the decision about value judgments entails the judgment of good or bad, better or worse; and that deciding truth or falsity is a cognitive process, while deciding better or worse is a political process" (Cohen, 1980, 31). Cohen redeneer dat waardes 'n bepalende rol in beide die feitelike en die normatiewe sfeer speel. Die feitelike en normatiewe aspekte funksioneer nie onafhanklik van mekaar in die samelewing nie (Cohen, 1980, 31-32). Die punt is dat waarnemings altyd kontekstueel of paradigmaties-bepaald is (Van Huyssteen, 1987, 59). Dit beteken dat die teologiese besinning oor kerk-wees bepalend moes wees in die opstel van die Kerkspieël-opnames, en nie slegs 'n empiriese (veral sosiologiese) benadering nie. Dit wil voorkom asof geoordeel is dat 'n sosiaal-demografiese opname op 'n positivistiese wyse kerklike feite sou oplewer en só 'n ware spieëlbeeld van die kerk sou deurgee. Die ontwerp van die navorsing, elke vraag in die vraelys, die keuse vir 'n steekproef - alles veronderstel egter ' $n$ sekere waarde en teoretiese oriëntasie. Dit blyk dat die Kerkspieëls nie regtig hierdie realiteit van navorsing verreken het nie.

Hierdie leemte in teoretiese besinning word vergestalt in die fokusskuif in Kerkspieël 1985 wat die politieke druk van die laat jare tagtig weerspieël. Die fokus van hierdie opname was, benewens die huishoudingsopname, ook om "helderder lig te werp op kernprobleme binne die raamwerk van die Ned. Geref. Kerk" (KS1985, 6). Hierdie opname het gekyk na die "lidmate se subjektiewe ervaring en/of belewing van eredienste, die gemeentelewe en die kerk as sodanig, ekumeniese aangeleenthede en selfs sosiale vraagstukke (rasseverhoudinge en etniese probleme) probeer peil wat die kerk in die posisie kon plaas om agter te kom wat aangaan in die harte en lewens van haar lidmate. Dit kan 'n belangrike bydrae lewer dat besluite wat in die naam van die kerk geneem word, minstens rekening hou met die sensitiwiteite van lidmate" $(K S 1985,6)$. Dit was 'n nuwe fokus, maar die teoretiese en metodologiese implikasies daarvan is nie verantwoord nie. 'n Opname wat toets vir houdings, oortuigings, beskouings of identiteite steun nog meer op teoretiese uitgangspunte as 'n sensus wat net beskrywend is. Kerkspieël 1985 se teoretisering is gebrekkig. Dit skep 'n ernstige leemte wat veroorsaak is deur die oordrag van Kerkspieël 1981 se metodologie na Kerkspieël 1985 sonder om die probleemstelling nuut te formuleer, teoreties te begrond en te beredeneer asook die implikasies vir die metodologie behoorlik te deurdink.

Die afsterwe van Sakkie van Eeden voor die finalisering van Kerkspieël 1989 het 'n groot leemte gelaat op die metodologiese verantwoording van Kerkspieël 1989 en waarskynlik ook verdere Kerkspieëls (KS1989, 2). Kerkspieël 1989 beklemtoon dat die metodologie van 
die vorige opnames behou is ter wille van vergelykbaarheid (KS1993, 163). Dit is egter nie slegs die metode wat vergelykbaarheid bepaal nie; die samestelling van die vraelys dra ook by tot vergelykbaarheid al dan nie. In Kerkspieël 1993 word die opname geskuif vanaf die aanvanklike sosiologiese benadering na 'n praktiese teologie-fokus. Hoewel die metodologie dieselfde gebly het, word in Kerkspieël 1993 opgemerk dat praktiese teologie oor teorie- en praxis-komponente beskik. Waarskynlik het die navorsers, tereg, die aanvoeling gekry dat die Kerkspieëls teologies begrond moet word. Daar word wel gemeld (KS1993, Inleiding) dat die metodologie vir vergelykingsdoeleindes dieselfde gebly het. Nogtans blyk dit dat die teoretiese oriëntasie (sosiaal-demografies na praktiese teologie) fundamenteel geskuif het, sonder dat die implikasies daarvan vir die metodologie verreken is. Die vraag is nie aan die orde gestel wat die beste wetenskap sou wees om die opname mee te rig nie - sosiologie as basisdissipline of praktiese teologie? Daar word ook nie gevra na die verhouding tussen die twee in die geval van interdissiplinêre samewerking nie.

Met Kerkspieël 1996 is die vorige opnames se metodologie behou. Hier word gemeld dat die doel is om 'n spieëlbeeld vir die kerk daar te stel wat kan lei tot ondersoek en wat die kerk die geleentheid kan gee "om te bid en te werk vir vernuwing" (KS1996, 1). Hoewel by Kerkspieël 1993 (Inleiding) en weer by Kerkspieël 2000 (vi) verwys word na die interaksie wat daar tussen die teorie en praxis in praktiese teologie behoort te wees, is dit duidelik uit die verslae dat hierdie verhouding nie gekonseptualiseer is nie. Hoe die brug van dít wat die praktyk vertoon en dít wat die teorie sê, oorkom moet word, is afwesig in die verslag. (Van Eeden, in KS1981, 8, het na hierdie aspekte verwys as: "wat 'is' en wat 'behoort' te wees".) Dit wil voorkom asof daar nie duidelikheid bestaan oor die doel van die Kerkspieël-verslae nie - oor watter verskil dit moet maak nie. As Kerkspieël 2000 dus skryf "om te bid en te werk vir vernuwing" (KS2000, s.p.) moet hierdie gebedskomponente en vernuwingsriglyne aangedui word. In so'n geval is die verslag dan sterk normatief en word 'n stewige teoretiese grondslag veronderstel. Hierdie begronding word egter nie in die verslae verskaf nie.

Oor Kerkspieël 2006 word geskryf dat “die Bybel 'n kernbron is in ons nadenke oor kerken gemeente-wees. Daarmee saam loop ons eie geloofstradisie en teologiese raamwerk wat bepaal hoe ons oor 'n gemeente dink. Kerkspieël probeer om sekere empiriese inligting in spel te bring. Dit gee data en statistiese gegewens van die kerk en gemeentes weer. Al die invalshoeke behoort in ons kritiese nadenke verreken te word" (Schoeman en Bisschoff, 2008, 3). Ook hier word die verbintenis tussen praktyk en teorie binne ' $n$ praktiese teologie-raamwerk bedink. Die gedagte is om "vanuit ons gereformeerde tradisie selfondersoekend en krities na onsself te kyk" (Schoeman en Bisschoff, 2008, 3). In Kerkspieël 2006 is die Church Life Surveys, wat in 1991 in Australië begin het, die vertrekpunt gemaak om spirituele en geloofsontwikkeling, aktiwiteite en verhoudinge in gemeentes, gemeenskapsbetrokkenheid van gemeentes en beskouings op die gemeentevisie te meet (Schoeman, 2006, 2). Hier is wel 'n nuwe meetinstrument en belangrike vergelykingsinstrument in Kerkspieël 2006 betrek. Tog word dit nêrens in vergelyking met die vorige opnames beredeneer, verdedig of verduidelik nie. Dit spreek vanself dat die metodologie wat in die Church Life Surveys met sukses in Australië benut word, nie summier sonder bepaalde aanpassings in Suid-Afrika toegepas kan word nie. Die onderliggende kerkbeskouing van hierdie opnames is nie geëvalueer nie, en daar word nie aangedui waarom dit in die konteks van die Ned. Geref. Kerk die beste strategie is om in Kerkspieël 2006 te volg nie. Dit blyk dat elke Kerkspieël 'n heeltemal onafhanklike opname geword het en dat die ideaal van 'n longitudinale studie heeltemal laat vaar is, sonder om dit te motiveer.

Die ondertoon van die aanvanklike Kerkspieëls was dat kennis gegeneer word deur feite te versamel deur van bewese opnametegnieke gebruik te maak. Dit word nie verreken dat ekklesiologie of praktiese teologie-teorieë daarin 'n meespeler is nie. In der waarheid kom die 
ekklesiologie oor die onderskeie opnames taamlik diffuus voor. Ook die keuses rakende watter feite versamel moet word, word nie teoreties-normatief bepaal nie. In latere Kerkspieëls word erken dat praktiese teologie-teorieë waarskynlik in die opnames ' $n$ rol moet speel. Nogtans is dit nie toegepas nie.

Die Kerkspieëls gaan dus mank aan 'n "teorie van kerk". Dít wat die kerk "behoort" te wees, is latent aanwesig, maar is nie in die opnames bewustelik verantwoord nie. Die vrae wat in die Kerkspieël-vraelyste opgeneem is, veronderstel sekere beskouings oor kerkwees. Dit is jammer dat die Kerkspieëls nie hierop gefokus het in die beplanning van die opnames nie. Hierdie oefening sou waarskynlik die resultate meer betroubaar en benutbaar gemaak het.

Samevattend kan dus gesê word dat die Kerkspieëls ' $n$ ernstige leemte toon aan ' $n$ probleemstelling wat teoreties verantwoord en duidelik is oor presies watter inligting vir die kerk in praktyk, plek en tyd noodsaaklik is. Die veranderings aan die fokus van die opname en die implikasies daarvan vir die uitvoering en vertolking van die opname is ook nie beredeneer nie. Hierdie leemtes in diepgaande metodologiese begronding van die Kerkspieëls kan ook waargeneem word in die proses van steekproefneming.

\section{STEEKPROEF}

In navorsing kan inligting van ' $n$ hele bevolking ingesamel word. Dit word 'n sensus genoem. Weens koste en praktiese oorwegings is dit gewoonlik moeilik om 'n hele bevolking te betrek. Daarom word van steekproewe gebruik gemaak. 'n Steekproef is 'n deelversameling van die totale bevolking. Indien vanaf 'n steekproef na die totale bevolking veralgemeen wil word, moet die steekproef aan sekere aannames voldoen. Hierdie aannames sal verband hou met die homogeniteit of heterogeniteit asook die grote van die bevolking. Hierdie onderafdeling beoordeel hoe daar van steekproewe in die Kerkspieëls gebruik gemaak is.

Kerkspieël 1 moes 'n sensusopname, en daardeur 'n huishoudingsopname, wees. Met laasgenoemde is bedoel dat ouderlinge die huishoudings in hulle wyk sou besoek om te bepaal wie Ned. Geref. lidmate is om só "verlore" lidmate ook op te spoor. Met Kerkspieël 1981 en 1985 is hierdie huishoudingsopname deur'n huishoudingsvraelys gedoen. Hierdie huishoudingsopname het met Kerkspieël 1981 'n telling by wyke opgelewer wat 6\% hoër (298 943 persone) as dié van saakgelastigdes was (KS1981, 16). In Kerkspieël 1985 was die oortelling 21\% (ongeveer 345 200 persone) (KS1985, 9). Met Kerkspieël 1989 is die inligting van die huishoudingsvraelys in 'n wyksvraelys oorgeneem. Die oortelling was 16\% (219 631 persone) (KS1989, 4). Vanaf Kerkspieël 1993 was hierdie opname nie meer suksesvol om "verlore" lidmate deur die wyksvraelys op te spoor nie $(K S 1993,4)$ - sonder om redes daarvoor aan te dui. Kerkspieël 1993 het 'n oortelling van 14846 persone opgelewer. Vanaf Kerkspieël 1996 is die verskil in telling tussen die wyksopname en die saakgelastigdes nie meer beredeneer nie - ook sonder om redes te verskaf.

Bogenoemde toon dat Kerkspieël 1981 en 1985 uniek was met die huishoudingsopname wat onderneem is. Dit het ook geslaag om verlore Ned. Geref. Kerk-geaffilieerdes op te spoor. Die wyksgegewens van Kerkspieël 1989 kon nog in 'n mate die huishoudingsopname se sukses voortsit om saakgelastigdes se ondertelling te peil. Vanaf Kerkspieël 1993 het die huishoudingsfokus egter ook by ouderlinge vervaag. Hierdie punt word gemaak om aan te dui dat die sensusopname van Kerkspieëls 1981 en 1985 veral Ned. Geref. Kerk-geaffilieerdes kon opspoor, maar dat die verdere biografiese inligting van hierdie sensus nie as volledige opname gehanteer kon word nie. Die rede was dat die kerk nie oor die bronne beskik het om die sensusgegewens te verwerk nie. Dit laat die vraag waarom daar dan nie vanuit die staanspoor steekproewe getrek is nie. Die gevolg was dat klein steekproewe van hierdie huishoudingsopnames getrek is - na afloop van die volledige opname. Met Kerkspieël 1981 was die grootte van die steekproef vir huishoudings 
2.65\% (14 715 vraelyste) en vir wyke 14.13\% (4 909 vraelyste). Waar huishoudingsvraelyste swak ingevul was, is dit uitgeskakel en met beter ingevulde vraelyste vervang. Die verslag dui egter nie aan wat die omvang hiervan was nie (KS1981, 11) en of seker gemaak is dat die vraelyste wat vervang is, ooreenstemmende kenmerke gehad het met dié wat dit vervang het nie. Al die saakgelastigdes se vraelyste is verwerk. Vanuit die gemeentes het 95.8\% (1 094) die vraelyste van saakgelastigdes ingestuur (KS1981, 10).

By Kerkspieël 1985 was die steekproef vir huishoudings ook 2.65\% (15 269 vraelyste) en vir wyke $11.87 \%$ (5 066 vraelyste). Al die saakgelastigdes se vraelyste is verwerk. Vanuit die gemeentes het 84\% (1 050) die saakgelastigdes se vraelyste ingestuur (KS1985, 219-220). Die formule waarmee die steekproef getrek was, was die wortel van n-tegniek - vir huishoudings: $10^{3} \mathrm{~V}(\mathrm{Wi}+\mathrm{I})$ en vir wyke: $3^{3} \mathrm{~V}(\mathrm{Wi}+\mathrm{I})$, waar $\mathrm{Wi}=$ wortelgetal $(\mathrm{KS} 1981,10)$. Hierdie formule is nie selfverduidelikend en die betekenis vanselfsprekend nie - meer inligting word benodig om die statistiese waarde daarvan te kan beoordeel. Daar kan dus nie gevolgtrekkings gemaak word oor die betekenisvolheid van die steekproefformule nie. Die navorsers het bevind dat die klein steekproewe wat getrek is, wel impliseer dat Kerkspieël 1981 en 1985 se inligting vir die kerk in die geheel betroubare inligting bied. Wanneer egter na sinodale vlak af beweeg word, begin dit minder betroubaar word en het nie meer nut op ringsvlak nie (KS1985, 220).

In Kerkspieël 1989 tot 2004 is 'n aangepaste steekproefneming gebruik deur van ' $n$ streekindeling ${ }^{5}$ gebruik te maak. Eerstens is ' $n$ sistematiese steekproef uit die aantal wyksen kerkraadsvraelyste getrek. Vir gemeentes met twintig wyke en minder is al die wyks- en kerkraadsvraelyste as deel van die steekproef beskou. Vir gemeentes met meer as twintig wyke is die wyke in twaalf verskillende intervalle verdeel. Om die aantal wyke te bepaal is ' $n$ formule gebruik waarin $\alpha$ 'n getal aan die onderpunt van die eerste derde van die interval verteenwoordig het. Dit is onduidelik wat hierdie formule presies was. Die formule is soos volg in die verskillende Kerkspieëls aangedui: Kerkspieël 1989: (V $\left.\alpha^{*} 20\right) \div 20$ (KS1989, 164), Kerkspieël 1993: (! $\left.\div \div 20\right) * 20$ $(K S 1993,168)$, Kerkspieël 1996: $(\sqrt{ }(2 a \div 20)) * 20(K S 1996,190)$, Kerkspieël 2000: $(\alpha \div 20) * 20$ (KS2000, s.p.), Kerkspieël 2004 het die formule weggelaat (KS2004, s.p.). Hierdie formule is ook gebruik om die aantal kerkraadslede te bepaal met $\alpha$ 'n getal aan die onderpunt van die eerste derde van die interval. Nadat die aantal wyke en kerkraadslede bepaal is, is elke n-de wyks- of kerkraadsvraelys getrek deur op 'n toevallige punt te begin. Uit elke sinodale gebied is daar dan weer 'n proporsionele steekproef van gemeentes getrek, wat volgens die vyf tipologiese streke ingedeel was. ${ }^{6}$ Die wyk- en kerkraadvraelyste van die getrekte gemeentes is dan gebruik. Vir die verwerking van die data is gewigte vir elke gemeente bereken, sodat veralgemenings vir die hele sinodale gebied gemaak kon word (KS1989, 164-166; KS1993, 167-169; KS1996 187-191; KS2000 s.p.; KS2004 s.p.). Net soos in die geval met die skribas is al die predikantsvraelyste verwerk, daar is dus vir die twee groepe geen steekproef getrek nie.

Vanuit die uiteensetting hierbo, blyk dit dat tussen die statistici en die Kerkspieëlnavorsers 'n begripsbreuk bestaan het. Die navorsers het nie regtig die steekproefproses begryp nie. Dit kan afgelei word uit die verskille in beide die steekproefformules wat in die verslae voorkom, asook die wyse van steekproeftrekking wat daarop dui dat die navorsers nie die formule of die proses begryp het nie en onverskillig daarteenoor gestaan het. Die korrektheid daarvan is nie gekontroleer nie. Die gerapporteerde inligting betreffende die formule is ook so beperk, dat die betekenisvolheid van die formule nie in hierdie artikel beredeneer kan word nie. As die navorsers nie die steekproefproses ten volle verstaan het nie, kon dit maklik gebeur dat hulle in die vertolking van die gegewens die aannames waarop die steekproeftegniek berus, kon

5 Die vyf tipologiese streke is: klein plattelandse, plattelandse, grootdorp, woonstel/buitengewone en voorstedelike gemeentes.

6 Sien voetnota 5 . 
oorspan het. Dat dit waarskynlik gebeur het, kan afgelei word uit die feit dat voortgegaan is met dieselfde soort tegniek van steekproefneming, al het die responskoers van die Kerkspieëls drasties afgeneem.

Die groot probleem met hierdie steekproefproses, is dat die steekproef getrek is op ' $n$ verminderde responskoers vanuit gemeentes in die opvolgende Kerkspieëls (sien Tabel 1). 'n Steekproef is ' $n$ deelversameling van 'n populasie. Namate die responskoers daal, word die steekproef ' $n$ deelversameling van die responderende gemeentes. Gevolglik kan dit nie regtig meer as ' $n$ deelversameling van al die gemeentes beskou word nie. Die Kerkspieëls se rapportering dat die inligting in die verslae betroubaar en geldig was, al was die steekproef later vanuit 'n responskoers van $47 \%$ getrek, was dus nie korrek nie.

In Kerkspieël 2006 was die steekproefneming egter herbedink en 'n nuwe tegniek ingespan. 'n Toevallige steekproef van $10 \%$ is uit die 1176 gemeentes in die Ned. Geref. Kerk getrek. 118 gemeentes was dus gekies en gevra om die vraelys in te vul. Op hierdie wyse is 12522 vraelyste terugontvang wat deur lidmate ingevul is. Hierdie vraelyste is tydens eredienste ingevul en verteenwoordig dus die meer getroue lidmate van die kerk. Dit bly dus debatteerbaar oor hoe 'n getroue spieël hierdie data kan gee van die lidmate van die Ned. Geref. Kerk in die geheel.

Dit is onduidelik waarom Kerkspieël nie vanaf die eerste opname van trossteekproefneming gebruik gemaak het nie. Ook waarom hulle nie die realiteit van vraelys-tamheid by respondente en medewerkers (o.a. kerkraadslede) voorsien en bestuur het nie. Beide strategieë kon ' $n$ heelwat hoër vlak van geldigheid en betroubaarheid in die opnames verseker het en potensieel 'n deurlopende hoë responskoers.

\section{RESPONSKOERS}

In die vorige onderafdeling is reeds verwys na die belangrikheid van die responskoers in die Kerkspieëls omdat die steekproewe daarop, in plaas van die bevolking, berus het. Die responskoers van die verskillende Kerkspieëls was soos hier onder aangedui.

Tabel 1: Kerkspieël: responskoers

\begin{tabular}{|c|c|c|c|c|c|c|c|c|}
\hline & \multicolumn{8}{|c|}{ Kerkspieël } \\
\hline & $\begin{array}{r}1 \\
1981\end{array}$ & $\begin{array}{c}2 \\
1985\end{array}$ & $\begin{array}{r}3 \\
1989\end{array}$ & $\begin{array}{r}4 \\
1993\end{array}$ & $\begin{array}{r}5 \\
1996\end{array}$ & $\begin{array}{r}6 \\
2000\end{array}$ & $\begin{array}{c}7 \\
2004\end{array}$ & $\begin{array}{r}8 \\
2006\end{array}$ \\
\hline $\begin{array}{l}\text { Terugvoer- } \\
\text { respons }\end{array}$ & $96 \%$ & $84 \%$ & $83 \%$ & $80 \%$ & $71 \%$ & $50 \%$ & $47 \%$ & $\begin{array}{l}81 \% \text { van die } \\
10 \% \text { steekproef. } \\
\text { In terme van } \\
\text { ver- } \\
\text { gelyk- } \\
\text { baarheid: } \\
8.2 \% \text { van } \\
\text { geheel. }\end{array}$ \\
\hline
\end{tabular}

Hierdie tabel toon hoe die entoesiasme van gemeentes om deel te neem aan Kerkspieël oor die jare afgeneem het. Hou in gedagte dat Kerkspieël 1981 tot 2004 grootliks dieselfde metodiek 
gevolg het. In hierdie Kerkspieëls is al die gemeentes betrek met Kerkspieël 2004 wat die laagste reaksie ontvang het deur van 553 gemeentes terugvoer te ontvang (KS2004, s.p.). Kerkspieël 2006 het heeltemal ' $n$ ander tegniek gebruik deur net 118 gemeentes te betrek deur ' $n$ steekproef waarin 95 gemeentes gereageer het (Schoeman, 2007, 2).

Die responskoerse toon interne ongelykhede. In Kerkspieël 1985 het die sinodes van NoordTransvaal ' $n$ 70\% en Natal 'n 73\% responskoers gehad. Hiervan meld Kerkspieël 1985: "Tendense en vergelykings vir hierdie twee sinodes hoef dus nie ernstig opgeneem te word nie" (KS1985, 220). Maar van die $84 \%$ responskoers van SWA in vergelyking met Midde-Afrika se $50 \%$ sê Kerkspieël 1985 dat van die twee sinodes is "ongeveer dieselfde terugrespons ontvang en ten spyte van die lae peil van samewerking sou tendense en patrone wat blyk uit die ontledings binne grense van waarskynlikheld redelik geldig wees" (KS1985, 220). Dat 84\% en 50\% terugresponskoers gelyk gestel word, toon die onverskilligheid wat op plekke in die Kerkspieëlverslae deurskemer.

Soos hierbo gemeld, is'n ernstige leemte van die Kerkspieëls dat wyks- en kerkraadslidvraelyste deur 'n steekproef bekom is, nadat die opname 'n sekere responskoers gerealiseer het. So ' $n$ metodologie is volgens die aannames van steekproefneming onhoudbaar. Dit word weggeredeneer deur ' $n$ argument soos in Kerkspieël 1989: "Die responskoers is meer as wat van so'n tipe studie verwag kan word. In die lig van die vorige twee opnames wil dit lyk of die koers bo $80 \%$ wil stabiliseer. Die doelwit moet bly om 'n deelname per sinode van bo die $85 \%$ te behaal" (KS1989, 168). Eerstens het die Kerkspieëls hierna nie weer 'n responskoers bo 80\% gerealiseer nie. Dit dui aan dat die responskoers in die verdere opnames nie met erns bestuur was nie. Tweedens is dit onhoudbaar in die logika van ewekansige steekproefneming om die steekproef te trek op 'n responskoers van $85 \%$ of $80 \%$ en dan nog steeds te veralgemeen na die kerk in die geheel. Die veralgemening kan slegs gemaak word na die responderende gemeentes toe. Die redenasie van ewekansige steekproefneming is dat dit vanuit die universum getrek moet word. Hierdie basiese uitgangspunt ontbreek in die Kerkspieëls, met Kerkspieël 2006 as uitsondering.

Ten spyte van die doelwit wat in Kerkspieël 1989 gestel is vir 'n responskoers van bo 80\%, word in Kerkspieël 1993 gemeld: "'n Baie goeie respons van 80.08\% is verkry. Die verskillende sinodale gebiede is dus, binne die grense van betroubaarheid, in staat om hulle posisie in 1993 met die van die vorige drie opnames te vergelyk" (KS1993, 170). Hier, sonder motivering, word $80 \%$ as 'n baie goeie responskoers beskryf, terwyl in Kerkspieël 1989 aangedui is dat dit verkieslik bo $80 \%$ moet wees. Natuurlik sou $80 \%$ 'n bevredigende syfer wees vir die saakgelastigdes se vraelyste, waarvan almal verwerk is. Vir die wyks- en kerkraadsvraelyste, waarvan egter 'n steekproef geneem is, kan nie beweer word dit val binne die grense van betroubaarheid nie omdat daar nie aan die aannames van steekproefneming voldoen is nie.

Kerkspieël 1996 handhaaf dié ongekwalifiseerde beskouing oor die responskoers: “' $n$ Redelike respons van $70.73 \%$ is verkry. Hierdeur word die verskillende sinodale gebiede dus, binne die grense van betroubaarheid, in staat gestel om hulle posisie in 1996 met dié van die vorige vier opnames te vergelyk." (KS1996, 188). Weereens sou geargumenteer kon word dat die skribavraelyste se inligting tot ' $n$ mate betroubaar beskou kan word, maar die wyksen kerkraadsvraelyste se inligting sal beslis daarbuite val omdat die steekproefaannames nie nagekom is nie. Kerkspieël 1993 se doelwit van bo $80 \%$ is by Kerkspieël 5 ongekwalifiseerd na 70\% verlaag. Kerkspieël 1996 meld: "Indien daar 'n volgende opname is, sal groot sorg aan die dag gelê moet word om te verseker dat meer as $70 \%$ van die gemeentes hulle vraelyste terugbesorg" (KS1996, 190). Geen bestuursredes word gemeld vir waarom die opname se responskoers met $9 \%$ gedaal het nie. Al wat gesê word, is: "Indien daar 'n volgende opname is, behoort ' $n$ responskoers van $80 \%$ as doelwit gestel te word. Met goeie administrasie behoort 
dit haalbaar te wees" (KS1996, 190). Ten spyte hiervan het die navorsingspan hulle in Kerkspieël 2000 begewe terwyl "die twee navorsers nie oor ' $n$ voltydse kantoor beskik om opvolgwerk te doen nie. In die geval van die 2000-opname is geen opvolgwerk gedoen nie" (KS 2000, s.p.). Die gevolg was dat die 2000-opname slegs ' $n$ responskoers van $50 \%$ opgelewer het. Dit stel 'n vraag oor die gewig wat hierdie ondersoeke op Algemene Sinodale vlak gedra het dat nie voldoende voorsiening vir infrastruktuur gemaak is nie. Ten spyte daarvan dat die vroeëre Kerkspieëls se responsdoelwitte eers "bo $80 \%$ " en toe "bo 70\%" gestel is, word in Kerkspieël 2000 gemeld: "Die responskoers van die opname is 'n redelike $50 \%$ en dra by tot 'n betroubare resultaat. In die geheel gesien, behoort al die sinodale gebiede op die patrone en tendense wat in die opname uitgewys word, te kan peil trek" (KS2000, s.p.). Daar word geensins gemeld nie dat die steekproefneming vanuit die wyks- en kerkraadsvraelyste teen hierdie responskoers betekenisloos geword het vir die kerk in die geheel.

Met Kerkspieël 2004 daal die responskoers tot $47 \%$ en word, sonder motivering, gemeld: "Met die oog op die betroubaarheid van die resultate is dit genoegsaam. In die geheel gesien, behoort al die sinodale gebiede op die patrone en tendense wat in die opname uitgewys word, te kan peil trek" (KS2004, s.p.). Weereens is dit 'n ongegronde stelling wat die steekproefneming van wyks- en kerkraadsvraelyste betref.

Die navorsingspan van Kerkspieël 2004 het klaarblyklik die opname aangepak sonder om die knelpunte van die vorige opname aan te spreek. Hierdie werkwyse blyk 'n tendens met al die opnames te wees. Weereens word gemeld dat "die twee navorsers nie oor ' $n$ voltydse kantoor beskik om opvolgwerk te doen nie. Soos in die geval van die 2000-opname, is ook met die 2004-opname geen opvolgwerk gedoen nie" (KS2004, s.p.). Dit is ook 'n vraag of 'n voltydse kantoor die probleem sou oplos. Kerklike vermoeidheid met Kerkspieël omdat dit nie in die Ned. Geref. kerk meer as betekenisvol beskou word nie en/of 'n verskeidenheid ander faktore kon aanleiding gee, lei tot 'n lae responskoers. Uit die verslae kom dit voor dat die Kerkspieëlopnames net meganies voortgesit is, sonder dat elke opname indringend metodologies en teoreties herbedink is. Dit kom ook voor dat die navorsers die sinodes verantwoordelik gehou het vir goeie terugvoer en dit nie primêr as hulle eie verantwoordelikheid beskou het nie. Onbevredigende responskoerse vanuit sinodes word na die sinodes weggekaats en aan swak samewerking uit daardie sinodes toegeskryf (KS 1981, 10; KS1985, 220), verder word verwag dat sinodes hulle responskoerse sal verbeter (KS1989, 166; KS1993, 169,) dat sinodes spesiale sorg moet dra dat hulle responskoerse verbeter (KS1996, 190) en dat sinodes beter resultate kan lewer (KS2000, s.p.).

Soos reeds gemeld, was Kerkspieël 2006 'n heeltemal nuwe soort opname. Die poging tot 'n omvattende opname is laat vaar en 'n gefokusde opname is gedoen. Selfs al was net 118 gemeentes in hierdie opname geselekteer, was die responskoers $81 \%$. Weereens word aanvaar dat dit betroubare resultate sal oplewer sonder dat argumente aangebied word oor hoekom die steekproeftrekking verteenwoordigend van die Ned. Geref. kerk sou wees. So 'n verduideliking is van kardinale belang in die lig daarvan dat hierdie getal slegs $8.2 \%$ van al die gemeentes van die Ned Geref Kerk voorstel.

Daar is 'n gebrekkige wyse waarop steekproefneming op wyks- en kerkraadsvraelyste in die verskillende Kerkspieëls toegepas is sonder om voortdurend te verseker dat aan die aannames van die tegniek voldoen word. Op grond hiervan kan die waarde van die resultate uit daardie vraelyste van die Kerkspieëls nie hoog aangeslaan word nie. Dit is duidelik dat die Kerkspieëls ernstige metodologiese gebreke getoon het weens 'n gebrek aan 'n behoorlike metodologiese begronding. 


\section{GELDIGHEID EN BETROUBAARHEID}

Geldigheid dui daarop of die data wat veronderstel is om gemeet te word inderdaad korrek, akkuraat en genoegsaam gemeet is (Bailey, 2007, 146; Bailey, 1994, 67; De Vos, 2010, 160). Sapsford $(2007,11)$ stel dit soos volg: "A research argument is said to be valid to the extent that the conclusions drawn from the data do logically follow them. Questions we must ask of every survey to test this involve: 1 . validity of measurement - the extent to which the data constitute accurate measurements of what is supposed to be being measured; 2 . population validity the extent to which the sample gives an accurate representation of the population which it is supposed to represent; 3 . validity of design - the extent to which comparisons being made are appropriate to establish the arguments which rest on them."

In die lig van die beoordeling van die Kerkspieëls se metodologiese uitgangspunte hierbo, moet ons die gevolgtrekking maak dat die Kerkspieëls se geldigheid bevraagteken kan word. Eerstens blyk dit dat die gebrekkig omskrewe teoretiese begronding van die opnames dit moeilik maak om presies te peil wat die navorsers met die opnames wou bereik. As dit nie duidelik is wat veronderstel is om gemeet te word nie, kan die geldigheid van die meting daarvan nie werklik beoordeel word nie. Tweedens blyk die steekproefneming van die latere Kerkspieëls (veral vanaf 1996) nie verteenwoordigend van die kerk in die geheel te wees nie en bring dit ook die Kerkspieëls se geldigheid in gedrang. Laastens is demografiese vergelykings met buitebronne (soos die Suid-Afrikaanse sensusse en kerkjaarboeke) in die eerste twee Kerkspieëls gedoen. In Kerkspieël 1981 en 1985 is die gegewens van die Kerkspieëls vergelyk met die Kerkjaarboeke en met die staat se sensusdata (KS1981, 11). Hoewel die inligting verskil het, is die verskille geïnterpreteer as dat dit steeds die geldigheid en betroubaarheid van die betrokke Kerkspieël ondersteun (KS1981, 11). Die syfers van hierdie inligtingsbronne is op verskillende tye ingesamel (wat soms meer as 12 maande verskil het) en hoewel soms hierna verwys is, is die impak van die tydsverskil op die ingesamelde inligting nie beredeneer nie. Die gebied wat Kerkspieël gedek het, het ook verskil van die gebied waar die sensusopname gehou is. Dit het nie Midde-Afrika en Namibië (voor 1990 Suidwes-Afrika) en voor 1994 die TBVC lande (Transkei, Bophuthatswana, Venda en Ciskei) ingesluit nie. Hierdie verskille in vergelyking in Kerkspieëls 1981 en 1985 asook die feit dat vergelykings in die latere Kerkspieëls vervaag het, bemoeilik die proses om die Kerkspieëls se vlak van geldigheid te bepaal. In die geheel beskou, is die gevolgtrekking dus dat die Kerkspieëls se geldigheid onder verdenking staan.

Betroubaarheid verwys na die stabiliteit of bestendigheid in die meting van ' $n$ metingsinstrument (Babbie, 2007, 146, Bailey, 1994, 72, De Vos, 2010, 160). In die Kerkspieëls se verslae word voortdurend verwys na die betroubaarheid daarvan (KS1981, 11; KS1985, 221; KS1989, 168; KS1993, 170; KS1996, 191; KS2000, s.p.; KS2004, s.p.; KS2006, s.p.). Uit al hierdie verwysings blyk dit dat met betroubaarheid bedoel word dat die resultate van die Kerkspieëls geloofwaardig is. Die punt is dat "betroubaarheid" in opname-terminologie 'n baie spesifieke tegniese betekenis het. In die geval van die Kerkspieëls sal dit dus verwys na die gehalte van die meetinstrumente (vraelyste) wat gebruik is. Om die betroubaarheid van vraelyste te bewerkstellig, moet die konsepte, op grond van 'n gekose teoretiese raamwerk, in verband gebring word met indikatore (vrae of stellings). Hierdie indikatore se verband met die konsepte moet beredeneer en gedemonstreer word. Om die akkuraatheid van die koppeling van indikatore tot ' $n$ bepaalde konsep te peil, behoort die meetinstrument deur voortoetsing en loodsondersoeke getoets te word. Hierdie sake kom nie in die Kerkspieël-verslae ter sprake nie. Dit beteken dat, op grond van hierdie verslae, nie 'n uitspraak gelewer kan word oor die betroubaarheid van die vraelyste in die Kerkspieëls nie. Gevolglik bring dit die geldigheid van die Kerkspieël-opnames in die geheel in gedrang. 


\section{AANBEVELINGS}

Enkele aanbevelings kan gemaak word met die bedoeling om die kwaliteit van die inligting te verbeter wat deur toekomstige Kerkspieëls tot die kerk se beskikking gestel word.

1. Met elke Kerkspieël sal daar 'n diepgaande ekklesiologiese besinning ${ }^{7}$ moet plaasvind wat in die betrokke Kerkspieël geoperasionaliseer word. Dit sal die probleemstelling van die Kerkspieël bepaal.

2. Indien die kerk opnames wil gebruik, moet kundiges in opnamemetodologie betrek word. Dit sal seker maak dat aan steekproefaannames voldoen word, dat die vraelyste betroubare meetinstrumente is en dat die geldigheid van die opname en die afleidings wat daaruit gemaak word bo verdenking staan.

3. Die kerk sal genoegsaam moet begroot om te verseker dat genoegsame kundigheid, middele en ondersteuningstelsels in plek is om betekenisvolle Kerkspieëlopnames te verseker.

\section{GEVOLGTREKKING}

Die Kerkspieëls van die Ned. Geref. Kerk het die potensiaal om vir die Ned. Geref. Kerk van nut te wees om te bepaal wat die stand van die kerk is in die lig van 'n gekose teoretiese raamwerk. Hierdie artikel toon egter aan dat die probleemstelling, steekproefneming, administrasie van die responskoers, die geldigheid en betroubaarheid van die Kerkspieëls ernstige leemtes toon. As die Ned. Geref. Kerk inderdaad die potensiaal van opnames, soos Kerkspieël, wil ontsluit, sal die hele projekproses van die opname hersien moet word om ' $n$ grondiger besinning oor die probleemstelling van die opname te verseker en op grond daarvan 'n paslike metodologie te ontwerp wat 'n peilbare geldigheid en betroubaarheid van die opname sal verseker.

\section{BIBLIOGRAFIE}

Babbie, E 2007. The practice of social research. Belmont, CA: Thomson Higher Education. Bailey, KD 1994. Methods of social research. Fouth edition. New York: The Free Press. Cohen, BP, 1980. Developing Sociological Knowledge: Theory and Method. Londen: Prentice-Hall De Vos, AS (red.) 2010. Research at grass roots for the social sciences and human service professions.

Third edition. Pretoria: Van Schaik.

Hugo, CJ 2009. The challenge of postmodernity for church ministry: a Practical Theology view in Praktiese Teologie in Suid-Afrika. Volume 24(2), 141-160.

Kruger, P. En Hofmeyr, JW 2009. Die NG Kerk en die era van verandering sedert 1990: Betekenis vir die NG Kerk se identiteit (Deel II) in Nederduits Gereformeerde Teologiese Tydskrif. Deel 50.

Nommer 3 en 4, 384-395.

KS1981 sien Van Eeden, IJ, Coetzee, CH, Nel, M, Prins, JG en Smuts jnr, M 1982.

KS1985 sien Van Eeden, IJ en Smuts, M 1986.

KS1989 sien Schoeman, WJ en Smuts, M 1989.

7 'n Diepgaande ekklesiologiese besinning beteken dat daar helderheid moet bestaan oor wat die Ned. Geref. Kerk as kerk beteken. Hoe die Ned. Geref. Kerk as kerk verstaan word as 'n instelling in 'n verhouding tot God en die samelewing moet uitgespel word. Teologiese en ander tydskrifte is vol van besinnings hieroor. Enkele voorbeelde is Hugo, CJ (2009), Kruger, P en Hofmeyr, JW (2009), Olwagen, JM en Nel, M (2009). Hierdie tipe besinning reflekteer egter nie in die Kerkspieëls se metodologiese aanpak nie. 
KS1993 sien Schoeman, WJ en Bisschoff, JH 2004.

KS1996 sien Olivier, G C, Schoeman, WJ, Smuts, M en Bisschoff, JH 1996.

KS2000 sien Schoeman, WJ en Bisschoff, JH 2000.

KS2004 sien Schoeman, WJ en Bisschoff, JH 2004.

Olivier, GC, Schoeman, W J en Smuts, M 1993. Kerkspieël IV. Pretoria: Ongepubliseerde verslag.

Olivier, GC, Schoeman, W J, Smuts, M en Bisschoff, JH 1996. Kerkspieël V. Pretoria:

Ongepubliseerde verslag.

Olwagen, JM en Nel, M 2009. Die liggaam van Christus-metafoor: perspektiewe op gemeentebou in Praktiese Teologie in Suid-Afrika. Volume 24(2), 248-273.

Sapsford, R 2007. Survey Research. Second Edition. Londen: Sage Publications.

Schoeman, WJ en Bisschoff, JH 2000. Kerkspieël 2000. Metodologiese verantwoording. Pretoria:

Ongepubliseerde verslag.

Schoeman, WJ en Bisschoff, JH 2004. Kerkspieël 2004. Metodologie. Pretoria: Ongepubliseerde verslag.

Schoeman, WJ en Smuts, M 1989. Kerkspieël III. Pretoria: Ongepubliseerde verslag.

Schoeman, K en Bisschoff, J 2008. Die plek van Kerkspieël in Kruisgewys, April 2008, 8/2, Wellington: Bybel-Media.

Schoeman, K 2007. The Congregational Life Survey in a South African church: strengths and weaknesses. Pretoria: Ongepubliseerde referaat.

Van Eeden, IJ en Smuts, M 1986. Kerkspieël II. Pretoria: NG Kerkboekhandel Tvl.

Van Eeden IJ, Coetzee, CH, Nel, M, Prins JG en Smuts, jnr, M 1982. Kerkspieël. Pretoria: NG Kerkboekhandel Tvl.

Van Huyssteen, W 1987. Teologie as kritiese geloofsverantwoording. Pretoria: Raad vir Geesteswetenskaplike Navorsing.

\section{TREFWOORDE}

Kerkspieël

Kerknavorsing

Ekklesiologie

Navorsingsmetodologie

Steekproef

Responskoers

Betroubaarheid

Geldigheid

\section{KEY WORDS}

Kerkspieël

Church research

Ecclesiology

Research methodology

Sampling

Response rate

Reliability

Validity
Prof SJ Zaaiman

Fakulteit Lettere en Wysbegeerte

Privaatsak X 6001

Potchefstroomkampus

Noordwes-Universiteit

Potchefstroom 2531

Tel. 018-2991627

Johan.Zaaiman@nwu.ac.za

Ds EJ Rautenbach

Voortrekkerstraat 19

Kakamas

8870 